\title{
'Herrenvolk' Democracy and Egalitarianism in South Africa and the U.S. South
}

\author{
KENNETH P. VICKERY
}

\section{Yale University}

Even a casual survey of recent history reveals that a society's devotion to democratic or egalitarian principles hardly rules out blatant racial oppression. Indeed, the two positions have often been deemed compatible. The democratic ideology professed by Europeans (or those of European descent settled elsewhere) has been drawn from the egalitarian thought of the Enlightenment. As Louis Hartz has indicated, Enlightenment thought on this matter can be interpreted either inclusively or exclusively-equality can be granted to all men, or only to certain categories of men. ${ }^{1}$ The seeming paradox of egalitarian rhetoric combined with obvious inequities is often resolved through defining members of some groups as outsiders-not a part of the 'Herrenvolk' or the 'people'-or even as subhuman.2

Pierre Van den Berghe has described what he calls a 'Herrenvolk democracy': 'a parliamentary regime in which the exercise of power and suffrage is restricted, de facto and often de jure, to the dominant group' ${ }^{3}$ a regime 'democratic for the master race but tyrannical for the subordinate groups'. ${ }^{4}$ Herrenvolk egalitarianism can be seen as the extension of equality in political, economic, or other spheres to those within the dominant group but not to those without.

Many observers have noted features of Herrenvolk democracy in South Africa, the South, or the United States as a whole. ${ }^{5}$ I hope here to place these concepts of Herrenvolk democracy and egalitarianism in a dynamic mode. David Brion Davis has suggested that 'prejudice against Negroes

1 Louis Hartz, 'A Theory of the Development of the New Societies', in Hartz, ed., The Founding of New Societies (New York, 1964), Chap. 1.

2 Pierre Van den Berghe, Race and Racism (New York, 1967), p. 18, and R. F. A. Hoernlé, South African Native Policy and the Liberal Spirit (Capetown, 1939), pp. 44, 127.

3 Van den Berghe, Race and Racism, p. 29.

4 Ibid., p. 19.

s Some examples: James Bryce, Impressions of South Africa (New York, 1900), Fp. 359-60; Maurice Evans, Black and White in the Southern States: A Study of the Race Problem in the United States from a South African Point of View (London, 1915), p. 3; René de Villiers, 'Afrikaner Nationalism', in Monica Wilson and Leonard M. Thompson, eds., The Oxford History of South Africa, v. II (New York and Oxford, 1971), p. 376; Hoernle, p. 2; Phillip Mason, Patterns of Dominance (Oxford, 1970), p. 326; W. M. MacMillan, Bantu, Boer, and Briton (Oxford, 1963), p. x. 
seems to have grown in the United States with the advance of popular democracy'.6 I wish to deal with the 'advances' in democracy-for whitesand the concomitant effects on race relations, in the U.S. South and South Africa. I shall concentrate my treatment on the nineteenth century and the early part of the twentieth. During this time there were periods when certain parallels in the histories of the two regions appear. In general, those periods marked by movements for greater democracy and equality among whites were marked also by greater oppression of non-whites.

There is, however, a crucial difference in the two cases. Lower-class whites in South Africa were far more successful than their southern American counterparts in achieving economic gains and security. Herrenvolk equality was a concept approaching reality in South Africa. In the South, it remained a myth.

There may be some disagreement over what constitutes a 'democratic' or 'egalitarian' movement, even if restricted to whites. I will take a broad view. Democratic movements may include those seeking more open, inclusive, or responsive political institutions, or greater power and representation for an underprivileged group. Egalitarian movements may simply strive for equal opportunity, or may be lower-class thrusts aimed at either true equality or a 'bigger piece of the pie'. The latter category has a particularly economic flavor, and economics will carry some importance in the analysis, especially in the later years. Of course, economic and political aspects are often, perhaps usually, combined in the movements discussed.

\section{JACKSONIAN DEMOCRACY, VOORTREKKERS, AND CAPE POLITICS}

Although their political situations were quite different, neither the U.S. South nor the Cape was very close to being democratic, even for whites, at the outset of the nineteenth century. In the first half of that century each area underwent change, both in relations among whites and in relations between whites and non-whites. Where there was progress toward democracy or equality for whites, there was frequently a diminution or limitation of the rights and opportunities of non-whites. Often, the same men were behind both trends.

Unlike the Cape, the South of 1800 was free from imperial control. The region was composed of self-governing states in a self-governing nation. Yet despite the radical egalitarianism pronounced during the American Revolution, the South's government remained 'thoroughly undemocratic',

\footnotetext{
6 David Brion Davis, 'The Comparative Approach to American History: Slavery', in Laura Foner and Eugene Genovese, eds., Slavery in the New World (Englewood Cliffs, N.J., 1969), p. 66. The article first appeared in C. Vann Woodward, ed., The Comparative Approach to American History (New York, 1968). Woodward, who pioneered in the dynamics of Herrenvolk democracy, makes similar statements about the South in Origins of the New South 1877-1913 (Baton Rouge, 1951), p. 211.
} 
to use Charles Sydnor's summation. ${ }^{7}$ As late as 1820 only three states had full white manhood suffrage, the rest imposing tax or property requirements. Local power in Virginia and elsewhere was vested in bodies of magistrates who elected their own successors. The legislatures were often weighted heavily in favor of the areas of the slave-holding aristocracy and against the upcountry farmers. The political structure reflected the economic structure, and the 'power to govern reposed far up in the economic pyramid of an agricultural society'. 8 As Clement Eaton has characterized the situation, the 'large body of commoners were prevented from playing a dominant role in politics by the property qualifications on voting, their lack of education, and, above all, by their own attitudes toward government. They were accustomed to follow aristocratic leadership'.9

All this began to change after 1820 . By that time a social movement strongly tied to democratic concepts was arising in the South and the rest of the nation. It was often identified by the name of the man who came to symbolize it, Andrew Jackson. The leader's background was ironic, perhaps: Jackson was a planter, a land speculator, and had sided with conservative interests on issues of money and banking in his home state of Tennessee. As Sydnor has put it, 'it is more accurate to say that democracy made Jackson than to say that Jackson made democracy'.10

In any case, agitation against entrenched powers increased rapidly in the 1820 s and resulted in a host of democratizing reforms in the 1820 s and 1830s. The small farmers of the newer south-western states and of the older states' upcountry regions were the backbone of the movement. Progress was more rapid and complete in the South-west. Part of the impetus for reform was economic; farmers and common men trained their wrath on the eastern banking powers after the Crisis of 1819 , and saw that political factors were shaping economic life more and more. ${ }^{11}$

The first major reform was to make the selection of Presidential electors dependent on popular election instead of the legislature. This was accomplished in all the southern states save South Carolina by 1828.12 By the middle of the 1830s five states (Alabama, Mississippi, Tennessee, Arkansas, and Texas) could claim a popularly elected governor, universal white manhood suffrage, apportionment in both houses by the white population (this prevented slaveholders from increasing their power through the counting of blacks), provision for periodic reapportionment, and fairly representative county government. In five other states considerable progress was made toward these goals. Only the oldest and most aristocratic

\footnotetext{
${ }^{7}$ Charles Sydnor, The Development of Southern Sectionalism 1819-1848 (Baton Rouge, 1948), p. 38 .

${ }^{8}$ Sydnor, pp. 52-3. For an excellent discussion of the 'location of power' in the South at this time, see Sydnor, pp. 33-53.

${ }^{9}$ Clement Eaton, The Freedom of Thought Struggle in the Old South (Durham, 1940), p. 5.

10 Sydnor, p. 170.

11 Ibid., Chap. 5.

12 Ibid., p. 170.
} 
states, Virginia and South Carolina, clung to older ways, and they came under increasing pressure.13 Meanwhile, reforms similar to those in the South were being pushed through in the North.

How did blacks, slave or free, fare in this period? Virginia and North Carolina joined Maryland and Kentucky in taking from the free black the franchise he had heretofore possessed. All the new states of the South-west denied suffrage to the free black man. These processes were paralleled in the American North, where Delaware, Connecticut, New Jersey, and Pennsylvania disfranchised the black, and New York restricted his access to the ballot. The newer states of the North-west allowed no black voting, 14 and some of these states even prohibited blacks from residing within their borders. 15

Generally, slavery became more rigid and the status of slaves more proscribed in the forty years prior to the Civil War. Almost all southern states increased their restrictions on manumission and freed slaves (the latter were often required to leave the state or the country). Several states of the South-west, heart of the cotton regime, prohibited private emancipation altogether. Slave codes grew more restrictive in an effort to maximize control. ${ }^{16}$ Laws were passed severely punishing any agitation among slaves which might engender notions of freedom or rebellion.17 Nor, of course, was the crystallization of slavery reflected only in the law. This was the era which developed a Southern view of slavery as a 'positive good'. In both law and custom 'by the 1830 s slavery had assumed the rigidity of an entrenched institution'. 18

The extension of political democracy among whites, then, was accompanied by retrenchment in the status of blacks. The point to be emphasized here is that these two processes were part of the same social dynamics. They were the outcomes of two ideologies, 'Jacksonian democracy' and racism, which more often than not were fused in the minds of white people. The fusion was of lasting importance. As Woodward puts it, 'In that era racism and democracy formed a strange marriage, a union destined to be of fateful durability'. ${ }^{19}$

No writer has analyzed this 'strange marriage' more cogently for the pre-war period than George M. Fredrickson in his recent book, The Black Image in the White Mind. Fredrickson observes that

the Jacksonian movement . . . carried the rhetoric of popular democracy to an extreme almost unparalleled in American political history, while at the same time condoning a

13 lbid., pp. 275-88. See also, for democratic developments around the South in this era, Fletcher Green, 'Democracy in the Old South', in The Journal of Southern History, XII, 1946, pp. 3-23.

14 Green, p. 16.

15 C. Vann Woodward, The Strange Career of Jim Crow (Oxford, 1955), pp. 19-20.

16 Kenneth M. Stampp, The Peculiar Institution (New York, 1956), pp. 207, 232-5,

17 Eaton, passim, and Stampp, pp. 211-2.

18 Stampp, p. 28.

19 C. Vann Woodward, 'Our Own Herrenvolk', in New York Review of Books, XVII, 2, August 12, 1971, p. 11. 
form of anti-Negro demagoguery that anticipated the Southern race baiters of a later era ... Even the most radical spokesmen for 'the common man' ... went out of their way to emphasize that their 'democracy' was for whites only. 20

These Herrenvolk democrats were bolstered in their efforts by several important scientists of their age. Men like J. H. Van Evrie and Josiah Nott expounded the doctrine of polygenesis, or separate creation of the races, in which it was held not only that all blacks were genetically inferior, but that the superior whites were, to invoke the familiar phrase, created equal.21

The attention given to such reactionary southern ideologues as George Fitzhugh or Chancellor Harper, who framed visions of an organic society dominated by proper class distinctions, has obscured the importance of Herrenvolk egalitarianism in the defense of slavery. Fredrickson, however, has produced convincing evidence that 'Herrenvolk egalitarianism was the dominant public ideology of the South, because it was the only one likely to ensure a consensus'. ${ }^{22}$ This was because political democracy was no sham in the South by this time, especially in the South-west, as we have seen. Even Eric McKitrick, in introducing a volume largely devoted to the Fitzhugh strain of thought, concedes that in the ante-bellum South, the community's power was vested not simply in a few men, but in white men everywhere ...23 To endorse class distinctions among whites was impossible for any successful politician. Where the planting class was able to hold power, it had to do so by making a democratic appeal to the enfranchised non-slaveholding majority. 24

Conversely, however, when representatives of these lower class or yeoman whites came to power, they were often the most vehement defenders of slavery and exponents of black inferiority. Indeed, while avidly pronouncing the equality of all members of the white race, they did little to challenge the economic superiority of the planters. As Eaton concludes, the 'Jacksonian democrats made no efforts to disturb the vast complex of property rights involved in the institution of slavery'.25 Upward mobility, rather than equality per se, may have been uppermost in their minds. In fact, despite the fact that political democracy was 'vigorous, active, and noisy, . . . the people gained little in return for their votes' ${ }^{26}$

Thus there was a gap between the rhetoric of Herrenvolk equality and reality. (Given this fact, perhaps Andrew Jackson's background was

${ }^{20}$ George M. Fredrickson, The Black Image in the White Mind: The Debate on AfroAmerican Character and Destiny, 1817-1914 (New York, 1971), p. 70.

21 lbid., pp. 82-96.

22 Ibid., p. 68. Woodward has concurred with this view (see Woodward, 'Our own Herrenvolk', p. 14) and Hartz earlier presented a somewhat similar argument. He calls the southern reactionary enlightenment a 'fraud', and says 'there was no avoiding the fact that one of the crucial factors in the solidarity of the South was a democratic spirit enhanced by the slavery on which it rested. Hartz, The Liberal Tradition in America (New York, 1955), p. 168.

23 Eric McKitrick, Slavery Defended (Englewood Cliffs, N.J., 1963), p. 3.

24 Fredrickson, pp. 67-8. 25 Eaton, p. 29.

${ }^{26}$ Sydnor, p. 290. 


\section{4}

appropriate after all.) Clearly, the egalitarians could fight on two fronts: they could take on the aristocracy, or they could depress the blacks, thus decreasing the relative distance between themselves and the planters. They were willing to fight the planters in the political arena, but failed to translate successes here into social or economic gains. Instead they turned to defending slavery or disfranchising free blacks. Indeed, the status anxiety produced by the coexistence of an egalitarian ideology and an unequal reality may, as Fredrickson suggests, have contributed to the virulence with which the democrats pursued the second course. That course appeared, perhaps, as a most natural one. For as they saw it, it was with free blacks that depressed whites would have to compete.

At the close of the eighteenth century the Cape was still under imperial control. The Netherlands East Indies Company, which had ruled since 1652 , was about to give way to the British government, which finally established itself securely by 1806 .

The eighteenth-century Cape settlement was, in a sense, two settlements. The first consisted of Capetown and its environs, the second of the outlying frontier regions or platteland. In the first area the Company was predominant. A Governor and members of his Council of Policy, all Company officials, ruled in accordance with instructions sent from the Netherlands. A few members of the judicial organ, the Council of Justice, were burghers (permanent non-official residents), and these performed some consultative and administrative functions. But they had no power to make policy, and they were appointed by the Company. In general the government was an 'informal oligarchy', with the Governor at the top. Corruption was endemic. There is evidence that the burghers resented the Company as being basically a 'landlord and tax-collector'.27 However, there was little protest before about 1780 . T. H. R. Davenport suggests that this was due to the paramount power of the Company, the lack of a press, and the presence of the platteland to which dissidents could move. 28

'Class distinctions, in the European sense, did not apply within the white community ...'29 although there was more differentiation of status and occupation among Capetown whites than on the platteland. And, of course, beneath the Capetown whites there were large numbers of nonwhites-slaves, Coloured servants, and 'Free Blacks' (mostly liberated slaves and their descendants). But the western Cape in this period had no landed aristocracy as the South had. It was, however, even less democratic for whites because of the imperial position of the Company. According to

${ }^{27}$ This description of the western Cape is drawn from M. F. Katzen, 'White Settlers and the Origin of a New Society', in Wilson and Thompson, eds., The Oxford History of South Africa, v. I (New York and Oxford, 1969).

${ }^{28}$ T. R. H. Davenport, 'The Consolidation of a New Society: The Cape Colony', in The Oxford History, v. I, p. 311 .

29 Katzen, p. 232. 
M. F. Katzen, 'from 1652 to 1778 there was almost no progress toward democracy in the central government...'30

Out on the platteland, conditions were different. Formally, government in each of the two (later three) outlying districts was in the hands of councils consisting of a paid Company agent (landdrost) and a few unpaid burghers (heemraden). However, burghers often defied the Company (by refusing to pay taxes, for instance), and the Company could exert little genuine control. ${ }^{31}$ White men on the frontier were their own masters. They lived in a settlement that was egalitarian for whites, if any was; distinctions of wealth were minor and of little significance. In this atmosphere the whites forged a fierce individualism, great self-reliance, and a belief that no (white) man was better than the next. These attitudes bear resemblance to those held by Jacksonian democrats in America.

The platteland was egalitarian, then, and in some sense one can speak of a nascent frontier democracy. It would probably be closer to fact to call it a frontier anarchy. But whatever the case, it was of the Herrenvolk variety. If the frontier whites were their own masters, they also expected to be masters, completely, of the non-whites. Treatment of the latter was probably worse than around Capetown, and the racism more virulent. Khoikhoi who were not yet subjugated learned to make a distinction between representatives of the Company, from whom they could expect better treatment, and the platteland whites whom they avoided..$^{32}$

For the platteland burgher, any extension of equality beyond the Herrenvolk was inconceivable. MacCrone writes that when Jacobin ideas reached the frontier late in the eighteenth century, they were embraced, not only because they helped repudiate the Company,

but because they were a genuine reflection of the democratic spirit of frontier society. But outside the closed circle of that society they abruptly ceased to have any validity-a limitation which, in view of the relations prevailing with those to whom the doctrines were not considered to apply, appeared as a paradox even to contemporary observers. But, from the point of view of the frontier farmer, there was no real inconsistency in this attitude. 33

Any other attitude would mean being swamped in a sea of non-white, non-Christian creatures-a betrayal of the Herrenvolk.

Such was the state, then, of the Cape in the eighteenth century. The first half of the nineteenth would bring great changes in both white politics and race relations, most of them involving the new British presence. The relationship of race to two processes largely in the realm of white politics-

30 lbid., p. 214.

31 Katzen notes 'a visible list towards anarchy and contempt for the law in the platteland', p. 214. See also p. 233.

32 I. D. MacCrone, Race Attitudes in South Africa (Oxford, 1937), p. 119.

33 lbid., pp. 127-8. 


\section{6}

the establishment of new Afrikaner Republics and the development of some measure of self-government in the Cape-will be considered here.

The Afrikaner Republics (the Orange Free State and the South African Republic, or the Transvaal) were born as a result of the Great Trek. The Trek was a mass exodus from the Cape to the territories in the North, begun in 1836, and involving by 1845 some 14,000 white burghers, mostly from the platteland districts. It was a 'rebellion against the British government' and it was the intention of the Voortrekkers who participated to establish themselves as a 'free and independent people'. ${ }^{34}$

The reasons for this rebellion, or secession, are heavily bound up with race relations. From 1809 the British government, responding to missionary and humanitarian pressures, pursued an amelioration of the condition of slaves and Coloured in the Cape Colony. In 1809, a 'Hottentot Code' was promulgated, which was hardly revolutionary but did give the Coloured some legal standing. In 1812 the famous Black Circuit trials handed down punishments to white masters for violations of the code, thereby arousing tremendous resentment among burghers. ${ }^{35}$ Other incidents followed. In 1828 came perhaps the most important move, the passage of Ordinance 50, which abolished vagrancy and pass laws for the Coloured population (which were tools for controlling their labor) and placed them in a position of legal equality with whites. Then, in 1834, the emancipation of slaves was begun, to be completed by $1838 .{ }^{36}$

The anger felt by Afrikaners over these acts was intensified by the growing shortage of land and lack of security on the frontier, and the siding of the British government with the Xhosa enemy after the War of 1834-5.37 All this was really too much for many Afrikaners to take. As DeKiewiet has described their attitude: 'It was best surely to betake themselves across the border where there were water and free land and no British Government to disallow Vagrancy laws, and where white men could not be haled to court to answer the complaints of their servants'. ${ }^{38}$

So the Voortrekkers left the Cape. They established themselves initially in Natal, but almost all moved on after the British annexed the area in 1843 and insisted on the same distasteful conditions for non-whites. ${ }^{39}$ By the early 1850 s the two Afrikaner Republics were created, and treaties with Britain insured their independence.

${ }^{34}$ Leonard M. Thompson, 'Co-operation and Conflict: The High Veld', in The Oxford History, v. I, p. 406.

${ }^{35}$ MacMillan, Bantu, pp. 8-9.

36 Davenport, 'Consolidation', pp. 304-9.

${ }^{37}$ Ibid., p. 292.

${ }_{38}$ C. W. DeKiewiet, A History of South Africa, Social and Economic (London, 1941), p. 55. The racial causes of the Trek are also seen in this quote from the sister of one of the leaders: it was "not their freedom that drove us to such lengths, so much as their being placed on an equal footing with Christians, contrary to the laws of God and the natural distinctions of race and religion'. Mason, Patterns, p. 201.

${ }^{39}$ Leonard M. Thompson, 'Co-operation and Conflict: The Zulu Kingdom and Natal', in The Oxford History, i. I, pp. 372-7. 
The Republics, like the short-lived Natal experiment, were organized with the deliberate intention of establishing, or re-establishing, 'proper' relations between whites and colored, master and servant ${ }^{40}$-the sort of relations which had applied in the Old Cape platteland. Article 9 of the Transvaal constitution got straight to the point: 'The people are not prepared to allow any equality of the non-white with the white inhabitants, either in Church or State'. ${ }^{41}$ Other regulations prohibited non-whites from owning land, firearms, or houses, prevented them from political participation, and re-created the pass system. ${ }^{42}$ Slavery was not re-established (this was part of the price of British non-interference) but 'apprenticeship of African children taken in raids was begun, and the line between the two institutions was blurred'. 43

At the same time, whatever democratic tendencies for whites that were present in Cape frontier society were given greater form and substance. Representative legislatures were established which were the most powerful organs of central government. The franchise was made universal for white males, a step not taken in the Cape until 1936. These provisions had more relevance in the Orange Free State than in the Transvaal, which was racked by factions and divisions, and where local organization held the upper hand. 44

Herrenvolk egalitarianism was the dominant ideology of the whites. One burgher was as good as the next. De Kiewiet observes: 'The leaders of the community, even the President of the Republic, were accessible to him (the burgher). Though he lacked the exuberance of Andrew Jackson's followers who spread mud on the chairs of the white house to prove their democracy, his dislike of social pretension and class difference was the same'.45 And as on the Cape platteland, this egalitarianism reflected social and economic reality. The Republicans remained virtually undistinguished by wealth, occupation, or class. 46

Overall, the Trek and the founding of the Republics meant a more developed and secure democracy for whites and a rigidification of the subordinate status of non-whites. These developments are similar to those which took place in the American South in the same period. Of course the differences must be emphasized: the Voortrekkers created new nations, the Jacksonians only modified an existing system; the Voortrekkers had no urban, working-class component as the Jacksonians had in the American North. Most important, in the Republics there was genuine, thoroughgoing equality among whites; in the South equality did not go beyond the

${ }^{40}$ DeKiewiet, p. 181; MacMillan, Bantu, p. 20; and Thompson, 'High Veld', p. 408.

41 Thompson, 'High Veld', p. 430.

42 Ibid., pp. 435-6, and Thompson, 'Zulu Kingdom', p. 367.

${ }_{44}$ Leo Marquard, The Peoples and Policies of South Africa (London, 1969), pp. 11-12, and Thompson, 'High Veld', pp. 427-35.

4s DeKiewiet, p. $185 . \quad{ }_{46}$ Marquard, p. 11, and Thompson, 'High Veld', p. 426. 


\section{KENNETH P. VICKERY}

political sphere. To the upcountry, yeoman Jacksonian who was truly interested in equality (and not just mobility, as many Jacksonians undoubtedly were), the Orange Free State, for instance, might have been considered a veritable utopia-an ideal, rural, Herrenvolk democracy, the fulfillment of Jacksonian logic. There, 'equality... was an equality of privilege, and democracy was for the benefit of white society'. ${ }^{47}$ Such were the goals of many white men in both the American South and South Africa.

The transformation of Cape political institutions which took place in the first half of the nineteenth century stands, certainly on its surface, in contradiction to the pattern of developing Herrenvolk democracy. During this time the government of the Cape moved from the autocratic rule of the Dutch Company and the British Government to rule based on consent of the governed. By any standard, politics became more democratic. In 1783 an equal number of appointed burghers served on the Council of Justice with Company officials.48 During the first period of British rule (17951803) the burgher members became predominant on the Council and were also recognized separately as the Burgher Senate, with increased responsibilities. In 1827 two non-officials were added to the Governor's advisory Council, and in 1834 a Legislative Council with approximately as many burghers as officials was established. In 1836 elective government was instituted for the first time through the creation of municipal boards. And finally, in 1853, the major step was taken in the granting of representative government and the establishment of the Cape Parliament. ${ }^{49}$ These measures were granted by the Dutch and British in response to burgher agitation, which began with the Kaapse Patriotte movement of 1779-91,50 and continued with numerous petitions seeking self-government in the 1820 s. ${ }^{51}$ Thereafter, a vocal citizen press led Burgher protests. 52

Of course, this was also the period, as we have seen, of the emancipation of the slave and Coloured populations. Furthermore, when elective political institutions were granted, people of color were not specifically excluded. The established franchise, both for the municipal boards in 1836 and Parliament in 1853 , was color-blind, though it did carry certain property requirements. Coloured people could in theory vote and serve; some did vote and a few actually served on municipal boards. ${ }^{53}$ Thus it appears that in this case the extension of democracy for whites was accompanied not by a depression of non-whites, but by their advancement.

However, if one delves below the surface a bit, a somewhat different picture emerges. First, the inclusion of the Coloured people in the political framework was the result of British imperial authority. It is difficult to imagine the Cape burghers establishing a color-blind franchise on their

${ }^{47}$ DeKiewiet, p. 181.

48 Katzen, p. 228.

49 Davenport, 'Consolidation', pp. 313-24.

so Katzen, p. 228.

s1 J. S. Marais, The Cape Coloured People, 1652-1937 (London, 1937), p. 209.

52 Davenport, 'Consolidation', p. 317.

53 Ibid., p. 319. 
own-or if they had, the property disqualifications of Coloured would have been maximized. And, of course, slave emancipation and Ordinance 50 were British, not South African, projects. Second, even with the franchise that was established, overwhelming control was assured for whites through the property qualifications.

This white control, on a local level, meant that

the establishment of elective local institutions ... had much to do with the failure of Coloured people to advance their interests after emancipation ... Coloured people came to realize that more was to be had from 'the beneficent administration of enlightened magistrates' than from the elected representatives of their 'lords and masters'.54

MacMillan sees the 'guiding principle' of the municipal boards as 'the old desire to make the coloured people serviceable as "producers only" ', and notes the 'sorry story' of town administration of Coloured and African locations. ${ }^{55}$ Finally, at the level of central government, the Cape's liberalism declined after the granting of representative government in 1853 and responsible government in 1872.56 One of the first acts of the new Parliament was the 1856 Masters and Servants law, which established much stricter controls on the Cape's servants, who of course were mainly Coloured. In the 1860 s and 1870 s several 'quasi-discriminatory' laws were passed, dealing with liquor, cattle theft, and vagrancy, aimed at the newlyincorporated Xhosa population. ${ }^{57}$ Eventually the franchise was further restricted, but this matter takes us into the next section.

These points are not presented out of cynicism. Undoubtedly the Cape had many whites who were inclusive democrats and genuine liberals. Undoubtedly the Cape developments differed in important respects from the trends in the Republics and the U.S. South. But it does seem warranted to show that some of the dynamics of Herrenvolk democracy were operating here also.

\section{THE SOUTHERN AGE OF REFORM, AFRIKANER NATIONALISM, AND LABOR}

In the later nineteenth and earlier twentieth century, egalitarian movements arose among whites in both the American South and South Africa. In the South the movements were largely of a class nature, with lower- and later middle-class whites challenging the whiggish leaders of the 'New South'. Since the latter were often in league with northern business interests, the conflicts sometimes assumed a sectional character. In South Africa, the movements had both class and ethnic markings. Afrikaner nationalism tended to combine these two elements, despite the presence of

34 Ibid., p. 319.

ss MacMillan, The Cape Colour Question (London, 1928), pp. 269-70.

56 H. J. and R. E. Simons, Class and Colour in South Africa 1850-1950 (Harmondsworth, 1969), p. 31.

57 Marais, pp. 158, 204. 
a strong non-Afrikaner element in South African labor struggles (especially in the early years). It is in the sense that Afrikaner nationalism sought political power for the under-represented, freedom from outside control, social equality, and economic improvement for the proletariat that I consider it a democratic and egalitarian movement for the Herrenvolk. (There has been considerable vacillation over whether the Herrenvolk includes only the Afrikaners proper, or all whites loyal first to South Africa. The latter definition has usually prevailed in practice, if not in rhetoric.)

The conditions which gave rise to the movements in each area were largely economic, and characteristic of a certain stage of economic development. Because the South reached this stage somewhat sooner than South Africa, the bulk of events relevant for this analysis occur later in the second case.

In both places, the emergence of these movements in white politics had unfortunate consequences for non-whites. It is this aspect that I wish to trace here briefly.

At the end of Reconstruction in 1877 the leadership of the South passed into the hands of a class of men called Redeemers. Far from signalling the return of the old planter aristocracy, this era ushered into power unreformed Whigs of a capitalist, industrial, conservative outlook. ${ }^{58}$ The 'New South' was born, in which Henry Grady, its leading prophet, defended 'the right of character, intelligence, and property to rule'. In so doing he pronounced an elitest doctrine which implicitly excluded a large number of whites and thus rubbed against the tradition of Herrenvolk democracy which prevailed before the war. ${ }^{59}$ The Redeemers were more interested in class than caste. To this end, men like L. Q. C. Lamar and Wade Hampton established themselves as paternalistic protectors of the rights of blacks, whose votes they could count on against discontented lower-class whites. 60

The Redeemers and conservatives were challenged with some effect in the late $1880 \mathrm{~s}$, the $1890 \mathrm{~s}$, and 1900 s, first by agrarian radicalism and then by Progressivism. Even where the conservatives were able to retain power, they were forced, like the planters in the Old South, to bring their views more in line with the ideals of Herrenvolk democracy.61 Thus, in power or out, the class-based protection they offered to blacks fell into abeyance. Woodward comments: 'The barriers of racial discrimination mounted in direct ratio with the tide of political democracy among whites. In fact, an increase of Jim Crow laws upon the statute books of a state is almost an accurate index of the decline of the reactionary regimes of the Redeemers and the triumph of white democratic movements'.62

For a time, it seemed that the Populist movement of the $1890 \mathrm{~s}$ might

61 Fredrickson, pp. 266-7. 
break out of this pattern. The movement (like its forerunners, the Independents and the Farmers' Alliance) was born of the economic dislocations accompanying the transition from an agricultural to an industrial-based economy. The small farmers, black and white, found it increasingly difficult to maintain an independent existence on the land. Many were reduced to tenancy and sharecropping and most were victims of a harshly exploitative crop lien arrangement. Declining prices and crop trusts added to their woes. ${ }^{63}$ They found it necessary to confront a political regime blatantly in the camp of the industrial and commercial interests. The resulting Populist movement sought the alliance of southern and western farmers, farmers and their former neighbours now manning the mines and factories, and-most strikingly - white and black. ${ }^{64}$ For once, the bonds of race gave way to those of class; for once, democracy and equality were not confined to the boundaries of the Herrenvolk. The ideology of the white and black Populist was the "equalitarianism of want and poverty, the kinship of a common grievance and a common oppressor. As a Texas Populist expressed the new equalitarianism, "They are in the ditch just like we are" '.65 Tom Watson, perhaps the foremost exponent of the party, told the two races: 'You are made to hate each other because of the arch of financial despotism which enslaves you both ... the accident of color can make no difference in the interests of farmers, croppers and laborers'.66

The broad-based egalitarianism of the movement was short-lived, however. The conservatives threw their entire arsenal at the Populists, including the fraudulent counting of black votes, terrorism, and, above all, an appeal to race prejudice. No longer did they portray themselves as the black's protector; they made their bow to Herrenvolk democracy by emphasizing its racist side. When it became clear that the conservatives would go to any lengths to divide the Populists, and cheat them of the black vote anyway, the bi-racial partnership dissolved in frustration and bitterness. ${ }^{67}$

By the first years of the twentieth century, the Populists were broken. The remnants of the party joined with urban and middle-class interests, who felt the growing pressure of monopoly capital, in the southern Progressive movement. ${ }^{8}$ Far from adopting the non-racist strain of Populist ideology, however, the Progressives were instrumental in the deprivation of the black man's rights and the thoroughgoing extension of segregation and discrimination. The Progressive era corresponded precisely with the high tide of southern racism and caste domination. The southern Progressives were successful, however, in generating several democratic reforms for the benefit of whites.

63 Ibid., Chap. 7.

65 Woodward, Strange Career, p. 61.

${ }^{67} \mathrm{lbid}$., pp. 78-80.
64 Ibid., Chap. 9.

66 Ibid., p. 63.

68 Woodward, Origins, p. 371. 


\section{KENNETH P. VICKERY}

One 'reform', for it was cast in just such a term, was the disfranchisement of the black. The black vote had been the object of such manipulation and fraud that many old Populists and Progressives felt that the business of reform could get on only if this vote was eliminated. Even Tom Watson had become a Herrenvolk democrat of the first order by 1906 . He offered his support for the governorship to anyone who would back Populist/ Progressive reform and black disfranchisement. He found his man in Hoke Smith. ${ }^{69}$ Except in Mississippi, which set the precedent in 1890, disfranchisement came with the full impact of Populism and Progressivism. State after state took the vote from the black man between 1895 and 1910.70

Disfranchisement was not explicitly racial (this would have violated the Fifteenth Amendment), but relied on such ruses as literacy and educational tests, 'grandfather clauses', and a poll tax. Though there were loopholes left for poor whites, some of them lost the vote as well. ${ }^{11}$ This undemocratic move was largely offset, however, by the institution of the white primary, which in Woodward's view was 'undoubtedly an improvement over the old convention system and did much to democratize nominations and party control'.72 In Mississippi, for instance, with the establishment of the primary, the vast majority of whites, the poor farmers of the hill country, came into their own. ${ }^{73}$ Their representative, the radical reformer and racebaiter, James Vardmaman, was promptly elected governor.

The southern Progressives scored many of the same gains as their northern counterparts. In addition to primaries, they instituted initiative, referendum, and recall, and passed corrupt-practices and anti-lobbying acts. They busted and regulated trusts, established railroad and utility commissions, haled railroads into court, fought rate discrimination, and pushed through legislation on mine and factory safety, pure food and drugs, penitentiary reforms, and education and health care. In exactly the same years, the spectre of Jim Crow spread across the South, as discriminatory segregation was extended in schools, hospitals, courts, trains, waiting rooms, streetcars, sports, parks, residences, curfews and telephone booths. 74 As Dewey Grantham has summarized the movement, the strongest southern Progressives-those behind the major democratic reforms - were also the leaders of the anti-black moves. 'The Vardamans and Hoke Smiths might have represented "a genuine movement for a more democratic government in the South," as Ray Stannard Baker contended, but their democracy was for whites only and did great harm to the cause of the Negro and to good relations between blacks and whites. 75

${ }^{69}$ Woodward, Strange Career, p. 90.

71 Woodward, Origins, Chap. 12.

70 Ibid., p. 83.

73 A. D. Kirwan, Revolt of the Rednecks: Mississippi Politics 1876-1925 (New York, 1951), p. 135.

${ }_{74}$ Woodward, Origins, p. 373, and Strange Career, pp. 90-91, 97-102.

75 Dewey Grantham, 'The Progressive Movement and the Negro', in South Atlantic Quarterly, LIV, Oct. 1955, p. 465. 
Corresponding to the rising tide of segregation in other spheres was segregation in employment, and here it was anything but 'separate but equal'. In the first part of this century the concepts of 'Negro jobs' and 'white work' became well established, particularly in the minds of white workers. ${ }^{76}$ These former farmers, unable to subsist on the land and driven to the mines, mill villages, and urban factories, found themselves in competition, actual or threatened, with blacks. They kept up unrelenting pressure to drive blacks from the better work and further down in the job hierarchy. Indeed, it was pressure of this sort that dominated the labor movement, such as it was. There were probably more strikes in protest over the hiring of blacks than any other grievance. ${ }^{77}$ Thus, the 'advances' (if they can be called that) of the white proletariat were directly related to racial discrimination against blacks.

Southern industry was not highly organized, and those unions which did exist were usually restricted to whites, often with the toleration if not encouragement, of the American Federation of Labor. Race, then, constantly divided the lower class in the South. Employers were able to divert attention from wages and working conditions through the use, or the threat of the use, of black strikebreakers. In this they were abetted by men like Booker T. Washington, who counseled blacks to avoid unions and accept the benevolence of the conservative white factory owner. ${ }^{78}$ Thus were the wages and conditions of southern white workers kept miserably bad, and their economic security was minimal.

The white workers and farmers in the southern age of reform, like the yeoman Jacksonians before them, failed to use the advances they made to bring about white economic equality. The dominant capitalists of the New South were able to parry their thrusts, often using the issue of race. Indeed, later Progressives like Cole Blease and Theodore Bilbo came to concentrate on racism almost to the exclusion of reform. Pushing blacks still further down substituted for the material elevation of whites.

Among the goals pursued by Afrikaner nationalism from the late nineteenth century to 1939 were the elimination of British imperial control, wider participation in politics, the establishment of social, cultural, and economic equality of Afrikaners with the English, and the advancement of the white lower class. Broadly speaking, the first two of these can be seen as democratic, the last two as egalitarian. These four goals were joined by a fifth, pursued at the same time: the domination of non-whites and their relegation to a permanently subordinate status.

In one sense, of course, Afrikaner nationalism begins with the Great Trek and the establishment of the Republics. But in its modern form the

${ }^{76}$ F. Ray Marshall, Labor in the South (Cambridge, Mass., 1967), p. 11.

77 Woodward, Origins, pp. 222, 360.

${ }_{78}$ Marshall, pp. 33-5. 
movement's genesis can be dated from 1880, when South Africa's first political party, the Afrikaner Bond, was founded in the Cape. At this time politics at the higher levels in the colony did not much include rural Afrikaners (not to mention Coloured or Africans). ${ }^{79}$ The Bond procured much greater representation for this group and Afrikaner interests generally, and its leader, J. H. Hofmeyr, became one of the most powerful men in government. The rise of the party was one factor in the Cape franchise changes of 1887 and 1892, which had the effect of excluding from electoral politics many Africans who previously had qualified for participation. ${ }^{80}$

Afrikaner nationalism was forged and tempered in the fires of the South African War of 1899-1902. In de Villiers' opinion, the war did more to 'unite Afrikanerdom and infuse it with purpose and determination than any other factor before or after'.81 The Afrikaners lost the war, but emerged from it prepared to press their interests to the fullest. This meshed well with the policy of conciliation then being practiced by Britain. The result was that in the negotiations leading to the unification of South Africa in 1910, Afrikaner views prevailed to a considerable extent. Rural (i.e. predominately Afrikaner) constituencies were given generous representation. J. B. M. Hertzog-later to found the Nationalist Party-was successful in pressing for absolute equality of Dutch and English languages, a crucial condition for the survival of Afrikaner culture. Hertzog and other northern delegates campaigned against the color-blind franchise. They succeed in preserving the racial franchise in the north, in specifying that all members of Parliament must be white, and in laying a groundwork for a future erosion of non-white voting in the Cape. 82 Thus, achievement of a measure of equality for Afrikaners went hand-in-hand with an attack on the rights of non-whites.

By the time of Union, South Africa was in the throes of an abrupt economic transformation. The discovery of diamonds in 1866 and gold in 1886 had signalied the onset of an irreversible change away from an economy based, for people of all colors, on pastoralism and agriculture. Large cities and new industries sprang up quickly, and capital and skilled labor from overseas flowed into South Africa. People in rural areas, thrust into a market with fluctuating prices and beset by problems of population pressure, land shortage, drought, and poor cultivation methods, found it

79 Davenport, 'Consolidation', pp. 332-3.

${ }^{80}$ T. R. H. Davenport, The Afrikaner Bond: The History of a South African Political Party (Capetown, 1966), pp. 118-23; Leonard M. Thompson, 'Great Britain and the Afrikaner Republics, 1870-1899', in The Oxford History, v. II, p. 305: Leonard M. Thompson, The Cape Coloured Franchise (Johannesburg, 1949), pp. 6-7; J. L. McCracken, The Cape Parliament 1854-1910 (Oxford, 1967), p. 80; Leo Kuper 'African Nationalism in South Africa', in The Oxford History, v. II, p. 427.

${ }_{81}$ de Villiers, 'Afrikaner Nationalism', p. 367.

${ }^{82}$ Leonard M. Thompson, 'The Compromise of Union', in The Oxford History, v. II, pp. 325-64, and C. M. Tatz, Shadow and Substance in South Africa: $A$ Study in Land and Franchise Policies Affecting Africans 1910-1960 (Pietermaritzburg, 1962), p. 15. 
increasingly difficult to make a living in the countryside. Conditions were not unlike those obtaining in the American South a generation earlier. Poor white and poor black problems of large proportion developed, though whites saw only the former as worthy of concern. Many of the poor of both colors made their way to the cities, the mining and the industrial areas, where the only real hopes for employment lay. Mining alone employed 325,000 , of which 285,000 were black, by 1912 . Both push-and-pull factors, then, were at work in the urbanization process. ${ }^{83}$

The bulk of white laborers in South Africa, as in the South, took a 'whites only' view of the proletariat. They were much better organized, however, and the socialist pronouncements of many workers marked theirs as a Herrenvolk egalitarianism of a high order. It was the proud boast of the socialist-leaning Labour Party that it had been the first to call for total racial segregation in South Africa. ${ }^{84}$ As in the South, the most important strikes in the early years of the century were in protest over black labor replacing white. As the Simons describe the attitude of the workers on the Rand, the mining and industrial center of South Africa:

Experience of labour dilution convinced them that employers would substitute the cheaper coloured worker. A racial bar hardly needed justification in their eyes. It was a protective device ... Since the threat came from an alien and oppressed race, however, the trade unionists identified themselves with white supremacy so as to legitimate their class interests. ${ }^{85}$

In the early days the unions on the Rand were made up of skilled workers, mostly English-speaking. With time the movement became more broadbased and included more and more Afrikaners, though leadership of the unions and the Labour Party remained in English hands.

4,000 miners struck in 1907 over retrenchment of skilled white workers. Though defeated in this case, they were shortly able to bring sufficient pressure on government to pass the Mines and Works Act of 1911, which reserved certain skilled jobs in the mines for whites. ${ }^{86}$ This was a crucial precedent in South African history.

The real turning point, however, came in 1922. In that year the mine owners, faced with a 35 percent drop in the price of gold, announced plans to replace some white workers with black ones. ${ }^{87}$ The gold miners walked out and were joined by the coal miners; 22,000 struck in all. ${ }^{88}$ They claimed their action was taken to 'protect the White race' and 'preserve a White South Africa'. ${ }^{89}$ The Prime Minister, J. C. Smuts, chose to suppress the

${ }^{83}$ This description drawn from Frances Wilson, 'Farming, 1866-1966', in The Oxford History, v. II, pp. 114-29; Hobart Houghton, 'Economic Development 1865-1965', in The Oxford History, v. II, pp. 12-25; and David Welsh, 'The Growth of Towns', in The Oxford History, v. II, pp. 172-82.

84 Simons, p. 615.

8s Ibid., p. 89.

${ }^{86}$ Sheila Van der Horst, Native Labour in South Africa (London, 1942), pp. 179, 241, and Muriel Horrell, South African Trade Unionism (Johannesburg 1961), p. 3.

${ }^{87}$ Houghton, pp. 26-7. 88 Van der Horst, p. 182. 


\section{KENNETH P. VICKERY}

strike with force, and several weeks of violence ensued on the Rand, in which 247 were killed and 591 injured. Several instigators were hanged.90

Though the strike was ultimately broken, white South Africa was shocked by Smuts' tactics, and the Rand revolt spelled the end of his regime. In 1924 the Pact government came to power, an alliance of Hertzog's Nationalist Party (begun in 1914) and the Labour Party. By this time the 'poor white' problem was becoming critical. By 1932 there were about 300,000 whites classified 'poor', 90 percent of them Afrikaner. ${ }^{91}$ Such degradation of a class of whites offended the Afrikaner's sense of caste and Herrenvolk egalitarianism. Government action was imminent.

Hertzog, who had at least a share of power continuously for the next fifteen years, attacked the poor-white problem on three fronts. First, he sought to keep as many rural inhabitants on the farms as possible. To this end the state undertook to protect farmers from competing imports, and to stabilize prices well above international levels. These actions had the 'longterm social aim of keeping farm incomes more in line with those in town'.92

Second, the protection of white workers from competition through a color bar in employment was extended. The 1924 Industrial Conciliation Act set up union-management negotiation procedures, but excluded Africans from the process. The 1925 Wage Act empowered the government to set wages in non-organized industries, thus subverting the non-white worker's chance to undercut whites. The 1926 Mines and Works Amendment Act firmly re-established the reservation of skilled jobs in mining called for in the 1911 Act, which had been declared ultra vires by the courts. ${ }^{93}$ Acts such as these permanently eliminated the threat of competition from non-whites in employment, a threat not removed in U.S. South. The result was a greatly strengthened bargaining position for white labor.

Third, a policy of 'civilized labor' was adopted from 1924. The thrust of this program was that all whites should be given employment ahead of non-whites, and at a 'civilized .wage', i.e. several times what a non-white would receive for the same work. The government itself was one of the principal employers under this policy. For instance, from 1924 to 1933 the white percentage of those employed by the state-run railways and harbors went from 9.5 percent to 39.3 percent, while the African percentage dropped from 75 percent to 48.9 percent. ${ }^{94}$ Pressure to hire whites was also applied to the private sector. 95

The effect of these policies was noticeable but limited at first, especially during the depression years 1928-32. In conjunction with the boom which followed the abandonment of the gold standard in 1932, however, they largely achieved their aim. By the late 1930s, the poor-white problem was

\footnotetext{
${ }^{89}$ Simons, p. 278.

${ }^{92} \mathrm{~F}$. Wilson, pp. 137-40.

94 Van der Horst, p. 251.

${ }^{90}$ Horrell, p. 7.

91 Welsh, p. 76.

${ }^{93}$ Houghton, pp. 30-1, and Van der Horst, p. 183.

is Hoernle, p. 24.
} 
virtually a thing of the past. ${ }^{96}$ The concomitant, of course, was a severe limitation of the economic roles and power of non-whites.

On the political front, the Hertzog era presents a picture of increasing participation by whites and diminishing participation by non-whites. Hertzog presented his plan to remove Cape Province Africans from the common franchise in 1926, proposing that a Native Representative Council be established instead. He feared a deluge of black voters in coming years and wanted to ensure continued white control. After a ten-year delay, these measures were finally passed in 1936.97 The Council was little more than a powerless debating society, and its members boycotted it in 1948.98 In 1931 a law which permitted registrars to challenge non-white voters to prove their qualifications in person was passed, and this probably reduced the number of non-white voters in the Cape. 99

The reverse trend applied to whites. In 1930 women were enfranchised in the entire union. In 1931 the property qualifications for voting in the Cape and Natal were dropped, adding about 10,000 whites to the rolls. In debate on the second bill the Nationalist Malan invoked the northern principle that "every white man is a civilized person who ought to have the franchise'.100 These acts further diluted the remaining non-white vote in the Cape.

Finally, of course, in this era the patterns of discriminatory segregation were much elaborated. Building on the 1913 Land Act and the 1923 Natives Urban Areas Act, segregation was extended in a variety of ways: through pass laws in 1927 and $1932^{101}$; in restrictions on urban residency in 1930, and on extramarital sex in $1927 ; 102$ and perhaps most ominously by the Native Trust and Land Act of 1936, which established permanently the concept of separate black and white land, and re-affirmed the notion of blacks as 'temporary sojourners' in the city. In these acts were the harbingers of apartheid.

\section{CONCLUSION}

As in the first period sketched here, certain parallels in the histories of the South and South Africa emerge in the period of the late nineteenth and earlier twentieth centuries. In both, movements arose with ideologies embracing Herrenvolk democracy and egalitarianism. In both, reforms

96 Houghton, pp. $30,34$.

97 Tatz, pp. 46, 75, and de Villiers, p. 404. Hertzog did not wish to disfranchise the Coloured, and in fact proposed extending the Coloured franchise to other provinces. He was one of those who regarded the Coloured as allies vis-à-vis Africans. The franchise was never extended, however, and as early as 1922 other leading Nationalists favored Coloured disfranchisement. After 1948 this move was made.

98 Kuper, p. 455.

99 Marais, p. 280 . See Thompson, Cape Coloured Franchise, p. 56 for figures.

100 Tatz, pp. 65-6. 101 Kuper, p. 438.

102 Pierre Van den Berghe, South Africa: A Study in Conflict (Middletown, Conn., 1965), p. 126 . 
were legislated, affecting both blacks and whites, in accord with that ideology. In both, economic conditions, which obtained somewhat later in South Africa, were important stimuli, giving shape to the movements.

In South Africa, however, there was another stimulus, namely the presence of imperial Britain. Opposition to Britain meant that the movement there was a nationalist one and showed the greater determination and durability we might expect in such a case. Another difference between the two cases is the lack of the urban middle-class element in South Africa which occupied an important spot in southern Progressivism. Still another is the lack of a movement in South Africa like Populism which transcended, however temporarily, the bounds of one race-except perhaps for Communism, but the Communist Party never established much of a base in either race.

The most striking and important difference, though, is the much greater reality of Herrenvolk egalitarianism, in economic terms, obtaining in South Africa. The nationalists adopted policies specifically designed to eliminate the poor-white class, and, with the help of an economic upturn, they succeeded. There is to this day virtually no lower class of whites in South Africa. The same cannot be said for the American South. The age of reform produced only limited gains in the economic sphere for depressed whites. Many whites in the region remain impoverished.

The reasons may have something to do with the greater determination of a nationalist movement already mentioned; a people with a truly egalitarian past fought to preserve their culture. Further, when issues were phrased in terms of national survival, whether in the face of the 'imperial threat' or the 'black menace', lower-class whites had a stronger claim to support from their more fortunate brethren. The urban middle-class element in the southern reformers may also have been a factor; after all, they were middle in relation to a lower, and may have had a psychological stake in the presence of the latter. I would suggest that the difference also was related to the demographic facts of the two areas. The smaller white/ non-white ratio in South Africa made the permanent elevation of the white lower class possible, even within a capitalist framework. A vast army of non-white workers was forced, by the facts of political domination, to accept employment at a fraction of the value of their productivity. The difference was used to pay the exorbitant salaries of the whites, who were undoubtedly paid more than their real value. Such a solution was impossible for the American South; there were too few blacks to exploit and too many whites to support. 